\title{
OSWALD DE ANDRADE EM TORNO DE 1922: DESCOMPASSOS ENTRE TEORIA E EXPRESSÃO ESTÉTICA
}

\author{
Gênese Andrade \\ genese.andrade@terra.com.br
}

Oswald é um mistério lírico e sentimental arcabouçado por um corpo redondo e animado por um espírito raciocinante de financista. Usou barba flamenga e hoje é glabro como um galã de opereta. Escreve com os dedos em pinha, sobre cadernetinhas de capa de oleado. Some-se e reaparece, compra dúzias de palacetes e estátuas de dezenas de contos, lança um escritor como se fosse um perpétuo empresário do gênio.

$\left(\right.$ DEL PICCHIA, 1920) ${ }^{1}$

No dia 11 de fevereiro de 1912, praticamente dez anos antes da Semana de Arte Moderna, Oswald de Andrade partiu, no navio Martha Washington, para sua primeira viagem à Europa. Regressou em setembro do mesmo ano e se chegou a dizer que ele trazia na bagagem o futurismo, "fazia-se o primeiro importador" (BRITO, 1997, p. 25). Porém, na prática, nada confirma esse dado. A primeira menção ao futurismo no Brasil devese a Almacchio Diniz, no artigo "Uma nova escola literária”, publicado no

1. Salvo indicação em contrário, foram consultados os jornais e as revistas dos anos 1910 e 1920 em que os artigos aqui citados foram publicados. Os acervos ou sites das instituições a que as publicações pertencem estão indicados na bibliografia, em notas de rodapé. 
Jornal de Notícias, de Salvador, em 30 de dezembro de 1909, acompanhado do Manifesto Futurista, traduzido por ele, sem maior repercussão nesse momento (SCHWARTZ, 2008, p. 47; 401-402; 410-411).

Em suas memórias, Oswald recordou o conhecimento nessa ocasião da obra de Paul Fort, adepto do verso livre que lhe influenciara um poema, mas do qual não há vestígios, apenas recordações:

[...] Paris [...] dera-me o espetáculo da eleição de Paul Fort, vate livre, para príncipe dos poetas franceses numa noitada do "Lapin Agile", onde fui cair. Só assim vim a saber que se tratava, enfim, de desterrar do verso a métrica e a rima, obsoletos recursos do passado. Enganei-me redondamente pensando que isso tivesse qualquer autoridade no Brasil de Antonio Define. Uma aragem de modernismo vinda através da divulgação na Europa do "Manifesto Futurista”, de Marinetti, chegara até mim. Tentei um poema livre. Guardo até hoje o seu título. Chamava-se "O último passeio de um tuberculoso, pela cidade, de bonde". Mas a assuada dos Define me fez jogar fora o poema e com ele qualquer esperança de ver nossa literatura renovada (ANDRADE, 2002, p. 125).

Seria um texto precursor dos precursores, caso não tivesse se perdido, como ele rememorou em um poema inédito, escrito entre 1924 e 1927, intitulado "Reivindicação" (ANDRADE, no prelo):

Que pena

Não achar

Aquele Poema

Que eu fiz

Antes de todos

Os poemas

De Mário de Cendrars de Luiz Aranha e de Manuel

Eu trabalhei

Com um cinzel retardatário

Era O último passeio em 20 anos

De um tuberculoso

Pela cidade

De bonde

Dlen! Dlen!

Eu o poria neste papel

O título do poema pioneiro remete ao romantismo: a figura do tísico, que realiza o último passeio, associando morbidez e dramaticidade. Porém, sendo de bonde e pela cidade, anuncia o modernismo, que será marcado pelo movimento, pela velocidade e pelo cenário urbano. Antagonismo paródico, talvez.

Sendo assim, o futurismo se configurou em Oswald, nos anos 1910, mas como ausência ou perda, registro lacunar que existe apenas como 
memória e evocação. Ele confessou nas memórias que muitas coisas lhe escaparam na primeira passagem por Paris: "A esse tempo talvez eu estivesse, sem saber, ao lado de Picasso e Apollinaire no celebrado 'Lapin Agile' da butte Montmartre, [...]. Aí encontrei dois moços escritores, um crítico, Max Goth, e um medíocre fazedor de peças que se chamava Gabriel Reuillard" (ANDRADE, 2002, p. 117-118). Desse modo, Oswald não inovou em sua própria produção nem mudou a cena literária ao regressar da primeira viagem.

Nessa época, já estava às voltas com uma revista. Em agosto de 1911, juntamente com Voltolino e Alexandre Marcondes Machado, o Juó Bananére, fundara $O$ Pirralho, que circulou até fevereiro de 1918, em um total de 248 números. Aí estreou com as "Cartas d'Abax’o Pigues", criadas por ele e continuadas por Bananére, em dialeto ítalo-paulista; por seu caráter paródico e registro da oralidade, podem ser consideradas antecipadoras da poesia Pau Brasil, que Oswald começou a escrever em 1924 e publicou em 1925. Porém, predominava na revista a literatura parnasiana e simbolista. Oswald era bastante próximo de Olavo Bilac, Emílio de Menezes e Guilherme de Almeida, todos exímios sonetistas, assíduos frequentadores de suas páginas. Se ele soubesse contar sílabas - "Eu nunca conseguira versejar. A métrica fora sempre para mim uma couraça entorpecente. Fizera esforços grotescos para traduzir as 'perfeições' de Heredia” (ANDRADE, 2002, p. 125) -, talvez também não tivesse escapado à forma fixa.

Acabou por escrever textos em francês, em parceria com Guilherme de Almeida, em estilo simbolista. As peças Mon coeur balance e Leur Âme têm um caráter autobiográfico por parte de Oswald. Ele acabara de viver uma paixão desenfreada por uma jovem bailarina, Landa Kosbach, que conhecera no navio que o levara à Europa em 1912. A história complexa repercutiu na imprensa da época em tom de escândalo. Como recordou nas memórias:

Vazei, como já disse, minha desgraçada experiência amorosa nas duas peças que escrevi em francês com Guilherme de Almeida.

Refletem elas a descoberta da mulher, verídica no seu sexo e no seu destino (ANDRADE, 2002, p. 148).

Divulgadas em $O$ Pirralho e com trechos veiculados em A Cigarra e $A$ Vida Moderna em 1916, foram publicadas em livro nesse ano, com o título Thêatre Brésilien. Ao escrever em francês, Oswald e Guilherme de Almeida não eram exceção. Freitas Valle, senador e mecenas, mantinha a Villa Kyrial, importante centro de atividades culturais, nos anos 1910 e 1920, e publicava versos em francês, assinados como Jacques D’Avray. 
Sérgio Milliet, paulistano educado na Europa, também escrevia versos em francês e assinava Serge Milliet.

Na mesma época, Oswald começou a escrever Memórias sentimentais de João Miramar. Seus trechos, antecipados a partir de 1916 em O Pirralho, A Cigarra e $A$ Vida Moderna, não têm vestígios da linguagem inventiva, sintética e cubista que caracterizaria o romance, publicado em 1924.

Mas foi em $O$ Pirralho que Oswald publicou seu primeiro artigo sobre pintura: "Em prol de uma pintura nacional", estampado no número 168, de 2 de janeiro de 1915, focalizou os bolsistas do Pensionato Artístico, de volta a São Paulo em virtude da guerra. Aí destacou, entre os pintores nacionais, Almeida Júnior, embora tenha dito que não se poderia apontar em sua obra "a marca d'uma personalidade genial, estupenda, fora de crítica". Considerou-o "precursor, encaminhador e modelo", que não abandonara o elemento brasileiro em sua obra, mesmo depois da temporada de estudos na Europa: "É assim que vemos nele, posta em quadros que ficaram célebres, a tendência do tipo nosso, em paisagem, em estudos isolados de figura ou composições históricas de grupo". A ele, contrapunha os jovens pintores que, encantados com a arte europeia, tendiam a rejeitar o elemento nacional. Ressaltando a variedade e o vigor da paisagem e do tipo nacionais, reivindicava que os pintores que regressavam incorporassem-nos para construir a arte local:

E incorporados ao nosso meio, à nossa vida, é dever deles tirar dos recursos imensos do país, dos tesouros de cor, de luz, de bastidores que os circundam, a arte nossa que afirme, ao lado do nosso intenso trabalho material de construção de cidades, e desbravamento de terras, uma manifestação superior de nacionalidade.

Trata-se da defesa do elemento nacional, que viria a ser uma das bandeiras do modernismo. Porém, nesse texto, se deu a partir do elogio da obra de um pintor acadêmico, uma vez que a vanguarda europeia ainda não tinha repercussão no Brasil. Nesse momento, embora Vicente do Rego Monteiro, Victor Brecheret e Anita Malfatti já contassem com temporadas de estudos na Europa, o que vigorava aqui era a arte acadêmica. Tarsila do Amaral era aluna de Pedro Alexandrino. Lasar Segall fizera sua primeira exposição em 1913, em São Paulo e em Campinas, porém não causara nenhum impacto ou transformação no meio artístico, assim como a primeira exposição de Malfatti, em 1914.

Quase três anos depois daquele artigo, em 12 de dezembro de 1917, inaugurou-se a exposição de Anita Malfatti, cujos desdobramentos, após a dura crítica de Monteiro Lobato, são considerados o marco inicial do 
modernismo brasileiro. A artista teve em Oswald seu único defensor, em nota publicada no Jornal do Commercio, em 11 de janeiro de 1918, um dia após o encerramento da exposição:

[...] Numa pequena nota cabe apenas o aplauso a quem se arroja a expor, no nosso pequeno mundo de arte, pintura tão pessoal e tão moderna.

$[\ldots]$

[...] A impressão inicial que produzem os seus quadros é de originalidade e de diferente visão. As suas telas chocam o preconceito fotográfico que geralmente se leva no espírito para as nossas exposições de pintura. A sua arte é a negação da cópia, a ojeriza da oleografia.

[...]

A realidade existe, estupenda, por exemplo, na liberdade com que se enquadram na tela as figuras número 11 [O homem amarelo] e número 1 [Lalive]; existe, impressionante e perturbadora, na evocação trágica e grandiosa da terra brasileira que é o quadro número 17 [Paisagem de Santo Amaro]; existe, ainda, sutil e graciosa, nas fantasias e estudos que enchem a exposição.

Oswald exaltou sua originalidade e modernidade, a nova maneira de abordar a realidade, da qual, porém, a literatura ainda estava muito distante. Conforme depoimento de Anita Malfatti, publicado no Diário Carioca, em 24 de fevereiro de 1952, Mário de Andrade dedicou à tela $O$ homem amarelo um "soneto parnasiano" (Apud BRITO, 1997, p. 57); nas palavras do próprio poeta, estampadas na Folha da Manhã, em 24 de agosto de 1944, "um soneto, ricamente rimado, bem parnasianozinho" (Apud BRITO, 1997, p. 57).

Se esse fato, por um lado, selou o início da amizade, por outro, evidenciou o descompasso entre artes plásticas e literatura no cenário artístico brasileiro. O mesmo Mário de Andrade disse, anos depois, no texto "Fazer a história", publicado na Folha da Manhã, em 24 de agosto de 1944: "[...] eu, pessoalmente, devo a revelação do novo e a convicção da revolta a ela e à força dos seus quadros. [...] Foi ela, foram os seus quadros, que nos deram uma primeira consciência de revolta e de coletividade em luta pela modernização das artes brasileiras" (Apud BRITO, 1997, p. 65).

Em janeiro de 1920, deu-se a descoberta de Victor Brecheret, por Oswald de Andrade, Menotti del Picchia, Hélio Seelinger e Di Cavalcanti. Depois de uma temporada de estudos em Roma, ele regressara a São Paulo e ocupava uma sala no Palácio das Indústrias, transformando-a em ateliê. Lá foi descoberto pelo grupo que havia ido visitar a exposição de maquetes para o monumento à Independência, realizada no saguão do edifício, e então fora informado da presença do escultor, "um tipo esquisitão", que fazia "estátuas enormes e estranhas" (BRITO, 1997, p. 103). 
Em fevereiro de 1920, a Revista do Brasil publicou, no número 50, imagens de duas obras de Brecheret, acompanhadas por um texto não assinado, atribuído a Lobato. Em junho do mesmo ano, Oswald, com o pseudônimo Ivan, escreveu sobre o escultor no número 2 da revista Papel $e$ Tinta, a qual havia fundado, com Menotti del Picchia, no mês anterior. Com o título "Victor Brecheret", o artigo, embora tenha reconhecido que ele ainda não havia chegado "à completa maturidade intelectual", exaltou a modernidade do escultor, ainda quase desconhecido:

Escultor ainda tão ignorado que o conhecê-lo assume quase a proporção de um descobrimento, este brasileiro nos voltou há alguns meses da Itália, onde foi aprender o catecismo da arte que o enleva. [...]

$[\ldots]$

Mas Brecheret não reflete apenas as ideias modernas. Não é um espelho, é uma fonte viva de criação, impressionante na coerência com que junta à utilização eloquente do símbolo a sadia inocência dos primitivos. Compreendeu qual o valor da arcaização para que propendem esses escultores modernos [...]. Brecheret faz a sua escultura endireitar para o futuro apoiandose proficuamente nos preconceitos ancestrais, no alicerce de uma tradição reflorida na saudade. A Cabeça de Cristo, uma das suas criações magistrais, é de uma concepção originalíssima, belo na sua extravagância, denunciando um escultor com uma visão toda sua da arte. Naquela imobilidade pensativa, naqueles lábios sobrenaturais, no rictus da boca, nas tranças arcaicas o artista conseguiu prender, de modo genial, as tragédias, as esperanças, o sacrifício divino - todo um calvário de imolações formidandas. O Cristo de Brecheret é Deus.

A Eva serve de contraste. É a mulher da Terra, é a filha do limo, trazendo no sangue estuante o fogaréu interno do planeta, levando nos cabelos o cheiro verde dos vegetais e nos seios o milagre amoroso da germinação. Por isso ela enfia os dedos longos da mão esquerda na terra, num apoio de filha, enquanto com a mão direita acaricia as moedas lindas do pecado. Os novos jardins da Pauliceia clamam por que se lhes oferte para a glorificação a Eva de Brecheret.

São as duas obras melhores do escultor.

[...]

Como na nota sobre Malfatti, Oswald defendeu a modernidade estética. Destaca-se a negação da cópia dos modelos europeus e a defesa da arte não realista, a valorização do aspecto inovador e do elemento nacional - já defendido no artigo de 1915 -, apontando o trabalho original dos artistas brasileiros na releitura das vanguardas europeias. Embora não argumente extensamente, nesses textos já desponta a valorização dos elementos que pautarão a estética modernista.

Quando Washington Luís propôs, na esteira do centenário da Independência, que se fizesse também um monumento às Bandeiras, a 
maquete foi encomendada a Brecheret. Exposta na Casa Byington, em 28 de julho, foi acompanhada de um memorial descritivo. Porém, embora o artista fosse elogiado pela crítica, foi preterido no concurso. A maquete foi oferecida ao governo do Estado e depositada na pinacoteca pública (AMARAL, 1998, p. 87-92).

Em abril de 1921, o artista expôs, novamente na Casa Byington, a escultura $E v a$ - já exposta em Roma -, que foi bem recebida pela crítica paulista, inclusive por Lobato. Mas era um mármore clássico, com influência de Rodin, que fazia sua apresentação ao público. Os objetivos dessa exposição eram que a obra fosse adquirida pela Prefeitura e que Brecheret pudesse ir para Paris, com o patrocínio do Pensionato Artístico do Estado de São Paulo, ambos mencionados no citado texto de Papel e Tinta e logo alcançados.

No âmbito da literatura, as polêmicas e os descompassos não foram menores. Oswald aproximou-se de Mário de Andrade no Conservatório Dramático e Musical, no dia 21 de novembro de 1917. Ao ouvir o discurso de Mário em saudação a Elói Chaves, disputou-o para publicar no Jornal do Commercio, o que deixou o orador lisonjeado e deu início à amizade (ANDRADE, 2002, p. 160). Era, porém, um discurso bilaqueano.

No mesmo ano de 1917, foram lançados Há uma gota de sangue em cada poema, de Mário de Andrade; A cinza das horas, de Manuel Bandeira; Moisés e Juca Mulato, de Menotti del Picchia; Nós, de Guilherme de Almeida. Oswald só se pronunciou, nas páginas de $O$ Pirralho, sobre o último, o menos inovador de todos eles, embora nenhum pudesse ser considerado modernista de fato.

Após conhecer os versos que viriam a constituir o livro Pauliceia desvairada, Oswald publicou o artigo "O meu poeta futurista", no Jornal do Commercio, de 27 de maio de 1921, tirando autor e obra do anonimato. Depois de apresentar o poeta, sem dizer seu nome, exaltou o livro e transcreveu o poema "Tu", concluindo com o seguinte comentário:

Acharam estranho o ritmo, nova a forma, arrojada a frase? Graças a Deus! Podemos dizer que não só a França tem os seus Paul Fort, os seus Claudel, os seus Vildrac, e a Itália rejuvenescida o seu miraculoso Govoni. Nós também temos os nossos gloriosos fixantes da expressão renovadora de caminhos e de êxtases.

Bendito esse futurismo paulista, que surge companheiro de jornada dos que aqui gastam os nervos e o coração na luta brutal, na luta americana, bandeirantemente!

Oswald, com esse texto, juntou-se a Menotti, que vinha divulgando a poesia futurista em artigos no Correio Paulistano, dedicados a Agenor 
Barbosa, Govoni e a poemas de Marinetti. Se os artigos de Menotti não haviam provocado maiores reações, o de Oswald teve grande repercussão, a ponto de ser respondido no mesmo jornal em forma de soneto, com o título "Futuro condicional", cujo autor, não identificado, assinou apenas com a inicial "F.". Mário passou a ser ridicularizado nas ruas, perdeu alunos no Conservatório, onde lecionava, e talvez por isso negou veementemente o adjetivo que lhe fora atribuído, no artigo "Futurista?!", assinado como F. Liszt, publicado em 6 de junho de 1921: “o nosso poeta não se liga ao futurismo internacional, como não se prende a escola alguma"; "O poeta de Pauliceia desvairada não é um futurista e, principalmente, jamais se preocupou de 'fazer futurismo”'. Reiterou, no "Prefácio interessantíssimo", que abriu o livro publicado em 1922: "Não sou futurista (de Marinetti). Disse e repito-o. Tenho pontos de contato com o futurismo. Oswald de Andrade, chamando-me de futurista, errou" (ANDRADE, M. de, 1987, p. 61).

Diante da réplica de Mário, Oswald fez a tréplica em "Literatura contemporânea", publicado no Jornal do Commercio, em 12 de junho de 1921: "E não precisarei jurar que, em relação ao acanhamento de estética e ao embrutecimento tradicional do nosso país em cousas d'arte, os versos de Pauliceia desvairada são do mais chocante, do mais estuporante e, para mim, do mais abençoado futurismo". E fazendo um contraponto, afirmou: "não podemos parar na estética de monjolo dos senhores parnasianos de verso redondo". Negou a filiação a Marinetti e a Max Jacob, que seriam o futurismo no sentido estrito, declarou prosseguir na divulgação do "futurismo paulista" e apresentou também a obra de Guilherme de Almeida, Agenor Barbosa e Menotti del Picchia.

Naquela época, o que era novo, diferente, extravagante ou reação à arte tradicional era chamado de futurista; não estava ligado necessariamente ao movimento futurista italiano. Segundo Brito,

Pode-se dizer que esse artigo ["O meu poeta futurista”] de Oswald de Andrade deu nova vitalidade à palavra futurismo e suas derivadas. Antes, é exato, o vocábulo já era conhecido, e provocara, mesmo, rumor e polêmica. Mas, agora, correspondia a uma realidade nossa, não mais dizia respeito a uma situação apenas estrangeira. Os jornais, a partir desse momento até o fim de 1922 - e especialmente durante a Semana de Arte Moderna e os meses mais próximos de sua realização - estão repletos da incômoda palavra e seu emprego obedece a uma linha caricatural, aparece em quadrinhos, sátiras, sonetos humorísticos, em zombarias de toda a sorte, enfim. Futurismo e futurista - são palavras aplicadas a torto e a direito e a tudo quanto destrilhe da normalidade. Até a política se vê invadida por elas.

Corruptelas e deformações padecem também as malsinadas palavras. Os espíritos conservadores delas se utilizam pejorativamente, procurando pôr 
em ridículo pessoas, coisas, atitudes e situações. Elas, agora, não se aplicam mais somente a pintores e escultores ousados, mas também a homens de letras, a jornalistas, a chefes políticos. Os jovens escritores de São Paulo, se bem teimem em declarar que não são futuristas, valem-se delas como um "cartel de desafio", conforme proclamaria Menotti Del Picchia em discurso num dos festivais da Semana de Arte Moderna. Essas palavras são críticas, distinguem, separam, dividem. Para uns, representam nomes que identificam uma situação nova. Para outros, já inevitavelmente apodados de passadistas, têm gosto de insulto, de doesto, até mesmo de baixo xingamento (1969, p. 94).

Nesse contexto, talvez se possa dizer que a semente para a realização da Semana de Arte Moderna surgiu em torno de 1920, quando começaram os preparativos para as comemorações do centenário da independência do Brasil. Em 16 de maio de 1920, Oswald publicou, no Jornal do Commercio, o artigo "Arte do Centenário", no qual externava sua preocupação com a arte nacional, que não refletia uma verdadeira independência, demonstrando descontentamento com a produção do momento:

[...] a avalanche de obrinhas nacionais e estrangeiras que entopem o mercado é desoladora. Exposições, edições... Mas, senhores, é isso que vamos apresentar como expressão de cem anos de independência! Mas independência não é somente independência política, é acima de tudo independência mental e independência moral.

[...] é a expressão máxima da raça e de momento a obra de arte que resiste ao tempo; passam os politiqueiros, passam os tiranos que andaram de charola, passam os milionários e os agitadores de praça pública, apaga-se a memória dos que foram grandes à força de trombeta - e ficam os artistas.

[...] Cuidado, senhores da camelote, a verdadeira cultura e a verdadeira arte vencem sempre. Um pugilo pequeno, mas forte, prepara-se para fazer valer o nosso Centenário (Apud BRITO, 1997, p. 170; grifo do autor).

Ao participar do banquete oferecido a Menotti del Picchia no Trianon, por ocasião do lançamento de As máscaras, em janeiro de 1921, Oswald foi um dos que discursaram e se posicionou de forma mais explícita quanto à arte nova que despontava, apontando mais especificamente para a literatura. Falou "em nome de meia dúzia de artistas moços de São Paulo", "um grupo de orgulhosos cultores da extremada arte de nosso tempo", "um restrito bando de formalistas negados e negadores":

[...] para te lembrar a força que trazes no teu bojo prenhe de obrasprimas e te sagrar para combates mais vivos, que vimos assegurar-te guarda de honra no tumulto desta consagração de alta popularidade.

Venha talvez chocar, senhores, esse tinir de armas heroicamente arengadas em pacífica consagração literária, mas nós, que arrogantemente subimos os espantosos caminhos da arte atual, por força havemos de trazer, 
como soldados em campanha, um pouco do nosso farnel de assaltos. Somos um perdido tropel na urbe acampada em território irregular e hostil, e, como ela, temos a surpresa dos acessos e a abismada contorção das alturas.

[...]

São Paulo é já a cidade que pede romancistas e poetas, que impõe pasmosos problemas humanos e agita, no seu tumulto discreto, egoísta e inteligente, as profundas revoluções criadoras de imortalidades.

Assim, marcou a posição dos dissidentes e chamou Menotti à ação. Entregou-lhe uma máscara feita por Brecheret, assinalando que este fazia parte, juntamente com Di Cavalcanti, Anita Malfatti e John Graz, de "uma das mais fortes, expressivas e orgulhosas gerações de supremos criadores".

Em uma série de artigos que Oswald publicou na sequência, no Jornal do Commercio, a literatura foi o tema central. Em "Reforma literária", divulgado em 19 de maio de 1921, relacionou, embora sem exemplos, o futurismo na arte à sua realização na literatura e ao avanço em todos os setores em São Paulo, defendendo que o respeito pelo passado, pelo patrimônio, não podia frear o avanço dos jovens da metrópole:

E a questão paulista é uma questão futurista. Nunca nenhuma aglomeração humana esteve tão fatalizada a futurismos da atividade, da indústria, da história e da arte como a aglomeração paulista. Que somos nós, forçadamente, iniludivelmente, senão futuristas - povo de mil origens, arribado em mil barcos, com desastres e ânsias?

[...]

São Paulo avança numa afirmativa de maravilhas. A sua literatura liberada como a sua arte, tanto quanto a sua indústria e o seu comércio, têm que representar um alto papel e uma alta missão [...]

No mencionado "O meu poeta futurista", de 27 de maio de 1921, referira-se a Guilherme de Almeida e Menotti del Picchia como "criadores de uma poesia bem nossa, bem filha da São Paulo crepitante do Centenário”. Antes de exaltar Mário de Andrade, no trecho acima citado, afirmou: "Enganam-se sinistramente os que acreditam que São Paulo estaciona nas suas pequenas mãos moles de detentores de santinhos em corridas de literatura colegial"; "São Paulo ferve de arte boa e nova".

Já em "Paul Fort príncipe”, de 9 de julho de 1921, diante das críticas ao nomeado em 1912 "Príncipe dos poetas", que visitava o Brasil, voltouse para a questão literária a partir do confronto com o passado, que ainda vigorava:

Eis aí confirmado o que eu pensava celebrando a revolução futurista 
tentada por alguns espíritos superiores de São Paulo - estamos atrasados de cinquenta anos em cultura, vivemos chafurdados em pleno parnasianismo, agora quando o movimento simbolista é já uma reforma clássica.

E nada mais necessariamente lógico que assistir ao pasmo da ignorância nacional ante esta monstruosidade - um príncipe de poetas que nunca fez versos!

$[\ldots]$

[...] a ignorância que vai pelo nosso mundo oficial das letras é inominável. Estamos ainda em Heredia, em Leconte, em Hugo. Castro Alves - o batateiro épico da língua - é celebrado como o nosso primeiro poeta! E eu não erro se disser que muitos dos nossos acadêmicos ignoram não só Whitman, Laforgue e Apollinaire, como ainda a obra atavíssima de Paul Fort.

A literatura de hoje é, no entanto, dos mais esplêndidos surtos mentais humanos e nada os modernos escritores ficam a dever aos antigos. [...]

Não mediu as palavras para defender a renovação e atacar o passado, defendido pelos tradicionalistas. A mesma crítica ao expressionismo feita por Lobato em 1917, no âmbito das artes plásticas, repetia-se na área da literatura, ao rejeitar-se um poeta que fazia versos livres e era reconhecido na França. Mais uma vez, Oswald se pronunciou em desacordo.

Em "Reflexões críticas", publicado em 16 de julho de 1921, deu continuidade à crítica aos conservadores, com a mesma verve, e mencionou, ao mesmo tempo, os renovadores que viriam a participar da Semana de Arte Moderna, com os quais já estava em contato nesse momento e cuja obra apreciava, além daqueles que não eram tão próximos a ele. Destaca-se sua consciência de que alguns não estavam "incorporados às modernas correntes estéticas", embora tivessem a "larga visão nova":

A ignorância literária em que vicejam as trombudas árvores de nossa produção mental aumenta-se de seiva, com o coro jornalístico de analfabetismo letrado que constitui um dos mais preciosos fenômenos do humorismo pátrio.

[...]

A chegada de Paul Fort ao Brasil veio alvoroçar os nossos pró-homens do pensamento. Ninguém sabia quem era esse cabeludo que obtivera, num pleito triunfal, as máximas honras da cultura europeia. E quantos já se não dispunham a saborear um sonetinho patudo, daqueles de fecho de ouro, do ilustre viajante, quando se propalou a nova estupefaciente de que a sua obra - 23 volumes de baladas - não era afinal senão excelente prosa ritmada. [...]

[...] eu considero São Paulo [...] a glória revolucionária de Mário de Andrade, o divino futurista [...].

São Paulo é com o gênio renovador de Menotti e Lobato, a plêiade que vai de Serge Milliet a Agenor Barbosa [...]. São Paulo é, no tumulto civilizado do Rio, a aristocrática sensibilidade de Ribeiro Couto, [...] a cor e a visão de Anita Malfatti, de John Graz, de Regina Gomide Graz [...], a suprema elegância de espírito de Ferrignac [...] e a máscula energia de Brecheret. Nem todos 
incorporados às modernas correntes estéticas, esses espíritos esplêndidos pulsam, no entanto da coragem da nossa época, da alegria construtora da nossa civilização, da larga visão nova a que dá direito a festa de trabalho americano que faz a nossa vida.

Em “Questões de arte", de 25 de julho de 1921, a propósito da morte de Alphonsus de Guimaraens, defendeu-o como inovador, à frente do parnasianismo e precursor dos novos: "Hoje que uma estuante geração paulista quebra nas mãos a urupuca de taquara dos versos medidos, a figura de Alphonsus assume a sua inteira grandeza no movimento da boa arte nacional". Depois de criticar o realismo e o naturalismo de Zola e Eça de Queirós (autores por ele elogiados na época de O Pirralho), partiu para a defesa de Brecheret, retomando a crítica à arte que pretendia imitar a realidade:

A estilização de Brecheret - o nosso único escultor, mas que vale bem diversas gerações de modeladores - tem sido causa de debates contínuos na cidade. Não se compreende, por exemplo, que ele faça cavalos e homens com o pescoço desmesurado, ciclópicos de força majestosa e rápida, sem molezas ventrais nem detalhes orgânicos desvalorizadores.

Chegam diversos imbecis a crer que Brecheret não sabe que os cavalos e os homens que andam pelas ruas são diferentes dos que ele plasma. E dizem: mas onde já se viu uma perna desse tamanho, um pescoço desmedido assim, aquele pé está violento demais!...

Ignoram que Brecheret faz aquela arte propositadamente, pois que, como grande artista que é, sabe que a arte não é uma grosseira e inútil reprodução de exemplares de zoologia. Aqueles Bandeirantes que seriam, sem a força desmesurada dos seus músculos tensos, sem a caminhada heroica dos seus passos? Uma procissão idiota de nus familiares.

[...] Arte não é fotografia, nunca foi fotografia! Arte é expressão, é símbolo comovido.

Nesse artigo, Oswald fez um balanço das injustiças cometidas quanto à arte moderna, censurando a atitude de Raul Polillo com relação a Brecheret, que "fez esplêndidos reparos ao concurso do Centenário", e a de Lobato com relação a Anita Malfatti, "a palheta mais culta destas terras brasileiras e que aí está, desconhecida ou negada, para labéu da nossa civilização". Arrematou dizendo que Malfatti, Graz, Brecheret, Di Cavalcanti, os arquitetos Moya e Przyrembel seriam reconhecidos "mestres do nosso triunfante movimento de bandeirismo intelectual e artístico".

Quanto à literatura, afirmou que tinha até havia pouco "uma psicologia de jogo de prenda", e anunciou que Mário de Andrade publicaria nesse jornal uma "série faiscante de estudos profundos e argutos dos mestres do nosso extinto parnasianismo". Tratava-se de 
sete artigos intitulados "Mestres do passado", em que reconhecia o valor dos poetas como mestres, mas ressaltava que pertenciam a uma etapa encerrada. Desse modo, Oswald e Mário selavam o fim de um período e anunciavam o início de outro, que se inaugurou com a Semana de 1922.

No dia 8 de fevereiro de 1922, Oswald iniciou, no Jornal do Commercio, uma série de artigos sobre a Semana de Arte Moderna. Em "O triunfo de uma revolução", publicado nessa data, mencionou haver antecipado, no citado "Reforma literária", a "ofensiva" que estava prestes a iniciarse. Retomou os episódios de Anita Malfatti, Victor Brecheret e Mário de Andrade: o "erro brilhante" de Lobato quanto à apreciação da arte de Anita, as "bobices sensacionais" diante do Monumento às Bandeiras, de Brecheret, e o fato de Mário haver sido "sacrificado ao escândalo citadino". Questionou de modo incisivo: "Havemos de andar cinquenta anos atrás dos outros povos?", e defendeu mais uma vez que a arte acompanhasse a evolução em outros âmbitos: "O século contemporâneo do cinema, do telégrafo sem fio, das travessias aéreas intercontinentais, exige uma maneira nova de expressão estética”. Terminou defendendo Graça Aranha, cujo apoio foi fundamental para a realização do evento.

$\mathrm{O}$ artigo publicado no dia seguinte reiterou as mesmas ideias, com argumentação mais extensa voltada para a questão da pintura e a defesa do cubismo, além de se deter mais sobre Graça Aranha e A estética da vida. Juntou a este o nome de Paulo Prado como "os verdadeiros organizadores da demonstração de arte moderna que se prepara no Municipal”.

No terceiro artigo, de 10 de fevereiro, deteve-se no cubismo para defendê-lo, focalizando assim pintores europeus. Apresentou-o como o equivalente, para a pintura, do futurismo na literatura, referentes à arte moderna: "Cubismo é a reação construtiva de toda a pintura moderna. Assim, futurismo não é marinettismo e, sim, toda a reação construtiva da literatura moderna".

Ao se deter no futurismo, em 11 de fevereiro, Oswald aproximou-o do classicismo em oposição ao academismo: "o futurismo tem tendências clássicas. E é também o maior inimigo das academias". Para tanto, definia: "clássico é o que atinge a perfeição de um momento humano e o universaliza”; acadêmico "é cópia, é imitação, é falta de personalidade e de força própria”. E criticou a arte acadêmica de Bernardelli em escultura, Oscar Pereira da Silva em pintura, Carlos Gomes em música e Rosalina Coelho Lisboa em literatura. Assim, apontou o "futurismo paulista" como reação a isso: "façamos nós a revolução heroica e forcemos o andar lerdo dos intelectuais brasileiros que ainda acreditam na atualidade de Zola e Leconte"; "somos reacionários, porque nos domina e exalta uma grande aspiração de classicismo construtor". E concluiu: 
Queremos mal ao academismo porque ele é o sufocador de todas as aspirações joviais e de todas as iniciativas possantes. Para vencê-lo destruímos. Daí o nosso galhardo salto, de sarcasmo, de violência e de força. Somos boxeurs na arena. Não podemos refletir ainda atitudes de serenidade. Essa virá quando vier a vitória e o futurismo de hoje alcançar o seu ideal clássico.

$\mathrm{Na}$ véspera do início da Semana, o artigo publicado em 12 de fevereiro focalizou a música, atacou Carlos Gomes e exaltou Villa-Lobos. No grande dia, 13 de fevereiro, horas antes do início do evento, Oswald sintetizou-o:

Inaugura-se hoje no Municipal a Semana de Arte Moderna. Esperemos o veredicto do público de São Paulo. Ele travará conhecimento com o que há de mais avançado no mundo em escultura, pintura e arquitetura. Ouvirá o genial Villa-Lobos, que já começa a ser aplaudido em Paris. E a palavra gloriosa de Graça Aranha expor-lhe-á o que é a emoção estética na arte moderna. Ronald de Carvalho o representante autorizado da crítica atual, que já arrancou dois prêmios da conservadora Academia Brasileira de Letras, o reputado autor da nossa melhor história da literatura, falará também.

Nós, pelo acolhimento da plateia de hoje, julgaremos da cultura de nosso povo. Pois sabemos, com Jean Cocteau, que quando uma obra de arte parece avançada sobre o seu tempo, ele é que de fato anda atrasado.

A recepção do evento, que foi também chamado de "Semana Futurista” (FABRIS, 1994a, p. 140), já é exaustivamente conhecida. Decorridos dois dias do término, Oswald fez o balanço, em artigo publicado no Jornal do Commercio, em 19 de fevereiro:

A má fé de quatro patas exige que eu venha publicamente matar a palavra futurismo. É tempo.

Quem acompanhasse a campanha de renovamento estético que venho fazendo em São Paulo há cerca de um ano ao lado dos espíritos altíssimos de Menotti Del Picchia e Mário de Andrade veria que, pelo menos, por uma dúzia de vezes desmentimos o significado estreito do termo futurismo, a ele dando, quando empregávamos ou um sentido largo e universal, que abrangia toda a evolução moderna das artes, ou o sentido "paulista”, de renovação dentro das nossas cerradas fileiras provincianas.

Num ou noutro caso, não pode persistir a pecha idiota que alguns gazeteiros nos querem dar de que somos cangaceiros do Sr. F. T. Marinetti. Não somos.

[...] o que podíamos ser era "futuristas de São Paulo", personalíssimos e independentes não só dos dogmazinhos do marinettismo como mesmo de qualquer outro jugo mesquinho. Futuristas, apenas porque tendíamos para um futuro construtor, em oposição à decadência melodramática do passado de que não queríamos depender.

[...] o movimento não pode mais ser chamado futurista nem paulista. Trata-se de um movimento nacional, violento e triunfante e no qual se 
empenham reputações formidáveis.

Denominar-nos pois ainda de futuristas é renunciar à crítica pelo coice,

à discussão pela cretinagem peluda.

Ampliou o evento para além de São Paulo, devido à participação do grupo do Rio de Janeiro e, com agressividade, voltou a discutir o uso da palavra futurismo. Apesar das reações nos jornais e das vaias, concluiu que houve a vitória da arte nova.

No que se refere à participação de Oswald propriamente, embora fosse um dos principais arautos da Arte Moderna, com artigos publicados desde 1917, e também um dos principais organizadores da Semana, o que ele apresentou durante o evento foram trechos de um romance simbolista, Os condenados, primeiro volume de $A$ trilogia do exílio²

Em "Cartas a Crispim", publicadas no Correio Paulistano com o pseudônimo Hélios, Menotti del Picchia abordara Oswald, em 6 de novembro de 1920, e já o mencionara como "um dos maiores escritores da nossa terra", autor de dois romances inéditos. Em "Oswald de Andrade”, estampado no mesmo jornal, em 21 de abril de 1921, informara que ele havia começado a escrever $A$ trilogia do exílio no Carnaval de 1919, e divulgara um trecho da obra.

Como o próprio autor reconheceu em "O modernismo", publicado na revista Anhembi, postumamente, em 1954: "Eu levara comigo umas laudas, contendo uma página evocativa d'Os condenados, que nada tinha de excessivamente moderno ou revolucionário" (ANDRADE, no prelo). Lançado em 1922, pouco depois da Semana, as únicas inovações de Os condenados eram a técnica cinematográfica, a economia de meios e a ausência da divisão em capítulos; a construção dos personagens e a linguagem, embora novas, não eram ainda inovadoras. Tratava-se de uma obra realista, com elementos autobiográficos. Oswald pensava sobre o modernismo em artigos, mas escrevia romances fin-de-siècle. Era inovador ideologicamente, mas ainda não quanto ao estilo de sua criação literária. Se, quanto ao episódio Malfatti/Lobato, Annateresa Fabris apontou a "existência de uma expressão moderna dissociada da presença de uma crítica moderna” (1994b, p. 20), no caso da atuação de Oswald no âmbito literário, pode-se dizer que ocorreu o contrário, pois a teoria antecipou a práxis (p. 22).

2. O segundo volume é $A$ estrela de absinto, publicado em 1927, e o terceiro, $A$ escada vermelha, de 1934. A trilogia do exílio foi republicada em $1941 \mathrm{em}$ um só volume, com o título Os Condenados, alterando-se o título do primeiro e do terceiro volume, respectivamente, para Alma e A escada. 
Constata-se, no conjunto das obras expostas e apresentadas na Semana, a permanência do descompasso entre a literatura e as demais artes3. Exceto os poemas de Pauliceia desvairada e "Os sapos", de Manuel Bandeira, declamado por Ronald de Carvalho, já que o autor não pudera comparecer, as obras literárias aí apresentadas estavam longe de ser os textos emblemáticos da revolução modernista. No âmbito das artes plásticas, vários dos trabalhos apresentados eram inovadores e anteriores a 1922. Anita expôs algumas das telas que haviam figurado na polêmica exposição de 1917. Brecheret e Rego Monteiro estavam na Europa quando o evento se realizou, mas haviam deixado obras que foram expostas, datadas, respectivamente, de 1920 e 1921.

Brecheret inspirou obras literárias lançadas em 1922. Mário de Andrade atribuiu a uma escultura dele - Cabeça de Cristo, mencionada no artigo publicado em Papel e Tinta, em junho de 1920, e logo depois adquirida pelo poeta ${ }^{4}$ - a eclosão dos versos de Pauliceia desvairada. Menotti del Picchia inspirou nele personagem de $O$ homem e a morte e Oswald fez o mesmo em $A$ trilogia do exílio. Além de sua caracterização em Os condenados, um trecho de A estrela de absinto, segundo volume da trilogia, foi publicado no Jornal do Commercio, em 14 de junho de 1921, com menção explícita ao escultor desde o título: "Páginas de atelier. Na partida de Victor Brecheret para a Europa”. Aí é apresentada a reação de críticos e de seus amigos à obra do personagem escultor, de volta ao país entre duas viagens à Europa, incorporando-se a crítica feita a Anita Malfatti por Lobato. Ao ser publicado em 1927, o livro teve capa de Brecheret. Oswald já havia encomendado a ele o busto de Daisy 5 - a musa de sua garçonnière mantida em 1918, jovem ousada com quem se envolvera e que, precocemente falecida, casara-se com ele in extremis.

Anita Malfatti fez a capa de Os condenados e de O homem e a morte, de Menotti del Picchia. Oswald adquiriu sua tela, Marinha, Monhegan ${ }^{6}$, de 1915, enquanto Mário comprou O homem amarelo $(1915 / 16)^{7}$, por ocasião da Semana de 22. Ambas haviam sido expostas em 1917.

3. O catálogo e o programa do evento foram incluídos, em fac-símile, em Caixa modernista (2003).

4. Essa obra integra a Coleção de Artes Visuais, IEB-USP.

5. Essa obra integra o Acervo Artístico e Cultural dos Palácios do Governo do Estado de São Paulo.

6. Essa obra hoje pertence ao Acervo do Instituto Moreira Salles, Rio de Janeiro (BATISTA, 2006, p. 275).

7. Ao longo do tempo, Mário adquiriu, ou ganhou, outras obras de Anita Malfatti (BATISTA, 2006), as quais integram a Coleção de Artes Visuais, IEB-USP. 
Segundo Aracy Amaral, “a exposição de artes plásticas da Semana de 22 apresentou antes intenções de modernidade que modernidade propriamente dita (fora as participações excepcionais de Anita Malfatti e John Graz)" (1998, p. 32). Já segundo Mário Pedrosa, no texto em que fez o balanço do evento trinta anos depois:

Sem a contribuição direta, primordial das artes plásticas, o movimento modernista não teria marcado a data que marcou na evolução intelectual e artística do Brasil. A sua própria orientação nacionalista, de descoberta e revelação do Brasil, não teria tido a sistematização, a profundidade, a busca de raízes com que se assinalou (Apud AMARAL, 1998, p. 292).

Embora seja evidente, nesse momento, o pioneirismo das artes plásticas, a liderança, antes e depois da Semana, coube a Mário e Oswald "por sua ação estimuladora e informativa" (AMARAL, 1998, p. 16). O evento deve ser considerado como um abridor de caminhos e teve continuidade com a revista Klaxon, concebida pelo mesmo grupo e publicada no mesmo ano a partir de maio, assim como com a produção literária e artística posterior a 1923, quando Oswald, em sua segunda viagem à Europa, teve, dessa vez sim, intenso contato com os artistas da vanguarda internacional, estabeleceu laços de amizade, divulgou a cultura brasileira e assimilou novas maneiras de olhar o Brasil e expressar sua arte.

Ao fazer um balanço do evento em 1944, no texto "Gênese da Semana de Arte Moderna”, Oswald rememorou, publicamente pela primeira vez, seu primeiro poema:

[...] fiz o primeiro poema modernista nacional de que tenho conhecimento. "O último passeio de um tuberculoso pela cidade, de bonde". Influência de que? De quem? Já do futurismo italiano que eu houvera conhecido na butte Montmartre, onde assistira à eleição de Paul Fort para príncipe dos poetas franceses?... Possível. Tudo possível. Menos, eu rimar, metrificar nos dedos, decorar os ritmos correntes. E talvez dessa subversão nativa, com o sentimento de encontrar uma hemoptise no bonde saíra o verso. $\mathrm{O}$ verso sim. Era verso. Nada de soneto, nem de elegia. Verso só, no singular (ANDRADE, no prelo).

Além disso, atribuiu ao encontro com Mário de Andrade, ao parque industrial e aos arranha-céus de São Paulo, a arrancada literária rumo ao modernismo. Mas reconheceu que o futurismo, que aqui era "algo nuevo" e exprimia "uma coeva independência”, já era velho na Europa.

Não deixa de ser revelador que o primeiro poema modernista, escrito dez anos antes da Semana de 22, traga em seu título o adjetivo 
"último" e um substantivo do universo romântico, "tuberculoso". Que tenha se preservado seu título em detrimento dos versos, sendo, assim, desconhecido, ou que ele seja ao mesmo tempo título e verso, inédito sem manuscrito, pura abstração. Que o futurismo e o cubismo causassem escândalo no país quando já eram passado na Europa. Que a arte moderna tenha sido defendida principalmente por um escritor cuja obra literária ainda não era moderna. Que fosse preciso voltar a Paris (mas que já vivia o "retorno à ordem") para "redescobrir" o Brasil e, enfim, acertar os ponteiros. A semana inaugural para a obra modernista de Oswald seria apenas dois anos depois, em fevereiro de 1924, quando passou o Carnaval no Rio de Janeiro com Tarsila do Amaral e Blaise Cendrars, escreveu o "Manifesto da poesia Pau Brasil" e o publicou em um jornal carioca, o Correio da Manhã, dando início ao movimento Pau Brasil e lançando a semente da Antropofagia. Na sequência, situa-se a Semana Santa passada nas cidades históricas de Minas Gerais. Havia que voltar aos elementos da cultura pré-colonial, colonial e popular e ao autóctone para fazer a literatura contemporânea da arte e das ideias modernas, do progresso econômico e da independência política.

\section{REFERÊNCIAS BIBLIOGRÁFICAS}

Obras de Oswald de Andrade

Livros

ANDRADE, Oswald de. Os condenados. São Paulo: Globo, 2003. . Estética e política (org.: Maria Eugenia Boaventura). $2^{\underline{\underline{a}}}$ ed. rev. e ampl. São Paulo: Globo, 2011. . Um homem sem profissão. Memórias e confissões. Sob as ordens de mamãe. São Paulo: Globo, 2002. . Memórias sentimentais de João Miramar. São Paulo: Globo, 2003.

_. Obra incompleta (org.: Jorge Schwartz). Paris: ALLCA XX; Archivos, no prelo. . Pau Brasil. São Paulo: Globo, 2010. Ils. de Tarsila do Amaral.

. O perfeito cozinheiro das almas deste mundo... Diário Coletivo da Garçonnière de Oswald de Andrade. São Paulo, 1918-1919. Edição fac-similar. São Paulo: Ex-Libris, 1987.

. Ponta de lança. São Paulo: Globo, 2004. . A utopia antropofágica. São Paulo: Globo, 2011.

ANDRADE, Oswald de; ALMEIDA, Guilherme de. Mon coeur balance/ Leur Âme/ Histoire de la fille du roi. São Paulo: Globo, 2003. 
Textos publicados em jornais e revistas

ANDRADE, Oswald de. Em prol de uma pintura nacional. O Pirralho. São Paulo, n. 168, S. p., 2 jan. $1915^{8}$.

. Nota sobre arte. Jornal do Commercio. São Paulo, 11 jan. 1918.9

. Arte do centenário. Jornal do Commercio. São Paulo, 16 maio 1920. ${ }^{10}$ Apud História do modernismo brasileiro. Antecedentes da Semana de Arte Moderna. $6^{a}$ ed. Rio de Janeiro: Civilização Brasileira, 1997. p. 169-170.

. [IVAN]. Victor Brecheret. Papel e Tinta. São Paulo, n. 2, s. p., jun. 1920"11.

. Reforma literária. Jornal do Commercio. São Paulo, 19 maio 1921.

. O meu poeta futurista. Jornal do Commercio. São Paulo, 27 maio 1921.

. Literatura contemporânea. Jornal do Commercio. São Paulo, 12 jun. 1921.

- Páginas de atelier. Na partida de Victor Brecheret para a Europa. Jornal do

Commercio. São Paulo, 14 jun. 1921.

. Paul Fort príncipe. Jornal do Commercio. São Paulo, 9 jul. 1921.

. Reflexões críticas. Jornal do Commercio. São Paulo, 16 jul. 1921.

. Questões de arte. Jornal do Commercio. São Paulo, 25 jul. 1921.

. O triunfo de uma revolução. Jornal do Commercio. São Paulo, 8 fev. 1922. ${ }^{12}$

. Semana de Arte Moderna. Jornal do Commercio. São Paulo, 9 fev. 1922.

. Semana de Arte Moderna. Jornal do Commercio. São Paulo, 10 fev. 1922.

. Semana de Arte Moderna. Jornal do Commercio. São Paulo, 11 fev. 1922.

. Semana de Arte Moderna. Jornal do Commercio. São Paulo, 12 fev. 1922.

. Semana de Arte Moderna. Jornal do Commercio. São Paulo, 13 fev. 1922.

Semana de Arte Moderna. Jornal do Commercio. São Paulo, 19 fev. 1922.

. Gênese da Semana de Arte Moderna. Hoje: o mundo em letra de forma. São Paulo, ano VII, n. 75, p. 12-13, abr. 1944. In: Obra incompleta (org.: Jorge Schwartz). Paris: ALLCA XX; Archivos, no prelo.

. O modernismo. Anhembi. São Paulo, n. 49, p. 23-32, dez. 1954. In: Obra incompleta (org.: Jorge Schwartz). Paris: ALLCA XX; Archivos, no prelo.

Conferência e discurso

ANDRADE, Oswald de. O caminho percorrido. Diário de S. Paulo, São Paulo, 23 e 30 jun. 1944. In: Ponta de lança. São Paulo: Globo, 2004. p. 162-175.

8. A única coleção original e quase completa (exceto o n. 241) de O Pirralho de que se tem notícia pertence ao Acervo da Biblioteca Mário de Andrade, São Paulo. A digitalização dos microfilmes dessa coleção está disponível em http://hemerotecadigital. bn.br.

9. Foram consultados os originais do Jornal do Commercio pertencentes ao Acervo do Arquivo do Estado de São Paulo, São Paulo.

10. Este artigo não foi localizado nos exemplares consultados do Jornal do Commercio, pertencentes ao Acervo do Arquivo do Estado de São Paulo, São Paulo.

11. Foram consultados os originais de Papel e Tinta pertencentes à Coleção Mário de Andrade, Biblioteca do IEB-USP, São Paulo.

12. Foram consultados os originais do Jornal do Commercio pertencentes ao Acervo do Arquivo do Estado de São Paulo, São Paulo. Estes artigos de Andrade em torno da Semana de 1922 também podem ser consultados em 22 por 22 (2000); alguns deles tiveram títulos atribuídos pela organizadora da obra. 
132 - Remate de Males 33.1-2

. Menotti Del Pichia. O almoço de ontem no Trianon. O que disse Oswaldo de Andrade. Correio Paulistano. São Paulo, 10 jan. 1921. ${ }^{13}$

Obras sobre Oswald de Andrade

BOAVENTURA, Maria Eugenia. O salão e a selva. Uma biografia ilustrada de Oswald de Andrade. São Paulo: Ex-Libris; Campinas: Editora da UNICAMP, 1995.

BRITO, Mário da Silva. Ângulo e horizonte. De Oswald de Andrade à ficção-científica. São Paulo: Martins, 1969.

CHALMERS, Vera M. 3 linhas e 4 verdades: o jornalismo de Oswald de Andrade. São Paulo: Livraria Duas Cidades; Secretaria de Cultura, Ciência e Tecnologia do Estado de São Paulo, 1976.

DEL PICCHIA, Menotti. Crônica social. Cartas a Crispim VII - Oswald de Andrade. Correio Paulistano. São Paulo, 6 nov. 1920.14

. Oswald de Andrade. Correio Paulistano. São Paulo, 21 abr. 1921.

ELEUTÉRIO, Maria de Lourdes. Oswald. Itinerário de um homem sem profissão. Campinas: Editora da UNICAMP, 1989.

FONSECA, Maria Augusta. Oswald de Andrade (1890-1954): biografia. $2^{\underline{a}}$ ed. São Paulo: Globo, 2007.

Outras obras

22 por 22: a Semana de Arte Moderna vista pelos seus contemporâneos (org.: Maria Eugenia Boaventura). São Paulo: Edusp, 2000.

AMARAL, Aracy A. Tarsila: sua obra e seu tempo. $3^{\mathrm{a}}$ ed. rev. e ampl. São Paulo: Edusp; Editora 34, 2003.

. Artes plásticas na Semana de 22. $5^{\mathrm{a}}$ ed. rev. e ampl. São Paulo: Editora 34; Fapesp, 1998.

ANDRADE, Mário de. Futurista?. Jornal do Commercio. São Paulo, 6 jun. 1921. ${ }^{15}$

O movimento modernista. In: . Aspectos da literatura brasileira. $6^{\mathrm{a}}$ ed. Belo Horizonte: Itatiaia, 2002. p. 253-280.

. Poesias completas. São Paulo: Edusp; Belo Horizonte: Itatiaia, 1987.

BATISTA, Marta Rossetti. Anita Malfatti no tempo e no espaço. São Paulo: Edusp; Editora 34, 2006.

13. O Correio Paulistano está disponível em http://hemerotecadigital.bn.br.

14. O Correio Paulistano está disponível em http://hemerotecadigital.bn.br.

15. Foram consultados os originais do Jornal do Commercio pertencentes ao Acervo do Arquivo do Estado de São Paulo, São Paulo. 
Brasil, $1^{\circ}$ tempo modernista - 1917-29. Documentação (org.: Marta Rossetti Batista et al.). São Paulo: IEB-USP, 1972.

BRITO, Mário da Silva. História do modernismo brasileiro. Antecedentes da Semana de Arte Moderna. 6ª ed. Rio de Janeiro: Civilização Brasileira, 1997.

Caixa modernista (org.: Jorge Schwartz). São Paulo: Edusp; Imprensa Oficial/ Belo Horizonte: Editora UFMG, 2003.

DEL PICCHIA, Menotti. O gedeão do modernismo: 1920/22 (org.: Yoshie Sakiyama Barreirinhas). Rio de Janeiro: Civilização Brasileira; São Paulo: Secretaria de Estado da Cultura, 1983.

FABRIS, Annateresa. O futurismo paulista. São Paulo: Perspectiva, 1994a. - Modernidade e vanguarda: o caso brasileiro. In: Modernidade e modernismo no Brasil (org.: Annateresa Fabris). Campinas: Mercado de Letras, 1994b. p. 9-25.

PEDROSA, Mário. Semana de Arte Moderna. In: AMARAL, Aracy A. Artes plásticas na Semana de 22. 5ª ed. rev. e ampl. São Paulo: Editora 34; Fapesp, 1998. p. 291-293.

SCHWARTZ, Jorge. Vanguardas latino-americanas. Polêmicas, manifestos e textos críticos. $2^{\mathrm{a}}$ ed. rev. e ampl. São Paulo: Edusp, 2008. 
